\title{
Coding of Tissue and Cell Products
}

\author{
Axel Pruß \\ University Tissue Bank, Institute of Transfusion Medicine; Charité - University Medicine Berlin, Berlin, Germany
}

With the Commission Directive (EU) 2015/565 of April 8, 2015 (amending Directive 2006/86/EC), certain technical requirements for the coding of human tissue and cells were defined. One of the central issues of this 'coding directive' was the mandatory use of a Single European Code (SEC) to ensure traceability from the donor to the recipient and vice versa in EU Member States. As basic modules, the first part of the European Commission involved the development of an EU coding platform with a tissue equipment register (EU Compendium of Tissue Establishments). The second part comprises of a product register of all tissue and cell products circulating in the EU, with respective corresponding codes (EU Compendium of Tissue and Cell Products; https://webgate.ec.europa.eu/ eucoding/). The tissue establishment registry shall include all tissue establishments performing licensed activities on human tissue, tissue preparations, or hematopoietic stem cells or stem cell preparations derived from peripheral blood or cord blood.

The suitable introduction of the SEC was a major challenge for tissue establishments in EU Member States. Therefore, this special issue mainly presents discussions on individual problems and modules associated with SEC implementation. One of the initial main problems was the provision of approved coding systems for cell and tissue products. Knels and colleagues [1] report on 'Eurocode' as one of these EU-licensed coding systems. It provides an international non-profit standard for labeling blood products and tissues to enhance safety in blood transfusion and tissue transplantation and is mostly used in Germany.

In addition, Ashford and Delgado [2] introduce ISBT 128 as another suitable tool for coding tissues and cells. ISBT 128 is the global standard for the terminology, identification, coding, and labeling of medical products of human origin (including blood, cell, tissues, milk, and organ products) and is provided by the International Council for Commonality in Blood Banking Automation (ICCBBA).

EUROCET is the official information tool for all European and extra-European citizens, patients, professional operators, and institutions and provides an overview of the 'European Registry of the Competent Authorities for Tissues and Cells'. Furthermore, EUROCET provides harmonized data regarding donation, procurement, testing, processing, preservation, storage, and distribution of human tissues and cells. Caramia and co-workers [3] explain the basic structures of EUROCET and specify future options at the European level. As previously mentioned, the introduction of the SEC in tissue establishments was difficult, especially in regards to its technical implementation. In their article, Schroeter et al. [4] discuss important constellations of problems and their solutions, reflecting initial experiences of SEC implementation in a multi-tissue bank.

Currently, an additional tool, termed the Global Registration Identifier for Donors (GRID), for the coding of hematopoietic stem and progenitor cells is approaching. The aim of global GRID projects is to create globally unique identifiers for unrelated donors and cord blood units. There are several advantages of having a globally unique donor identification (ID) number. These include reducing the risk of misidentification and misallocation, worldwide unique identification of the donor, standardized format of donor IDs, and simplified communication. Neller et al. [5] report on the next steps and the individual hurdles of achieving implementation on an international level.

\section{References}

1 Knels R, Stüpmann K, Pruß A, Klerke J, Kardoeus J, Hiller J: Coding of tissue and cell preparations using Eurocode. Transfus Med Hemother 2017;44:DOI $10.1159 / 000484416$.

2 Ashford P, Delgado M: ISBT 128 standard for coding medical products of human origin. Transfus Med Hemother 2017;44:DOI 10.1159/000479977.
3 Caramia V, Ghirardini A, Di Ciaccio P, Vespasiano F, Mareri M, Nanni Costa A: From the EU legislation to the application of the Single European Code: support to the implementation. Transfus Med Hemother 2017; 44:DOI 10.1159/000481144.
4 Schroeter J, Schulz T, Schroeter B, Fleischhauer K, Pruß A: Implementation of the Single European Code in a multi-tissue bank. Transfus Med Hemother 2017; 44:DOI 10.1159/000481145.

5 Neller J, Ashford P, van Veen C, Humpe A: Global Registration Identifier for Donors (GRID) of hematopoietic stem cells: road to automation and safety. Transfus Med Hemother 2017;44:DOI 10.1159/000485040.

\section{KARGER}

(๑) 2017 S. Karger GmbH, Freiburg

Fax +497614520714
Prof. Dr. Axel Pruß

University Tissue Bank, Institute of Transfusion Medicine

Charité - University Medicine Berlin

Charitéplatz 1, 10117 Berlin, Germany

axel.pruss@charite.de 